\title{
Pengaruh Independensi dan Profesionalisme Terhadap Kualitas Audit dengan Kepuasan Kerja Sebagai Variabel Pemoderasi
}

\author{
Gine Das Prena* dan I Wayan Angga Sudiartama \\ Universitas Pendidikan Nasional \\ *ginedp@yahoo.com
}

How to cite (in APA style):

Prena, G, D., Sudiartama, I, W, A. (2020). Pengaruh Independensi dan Profesionalisme Terhadap Kualitas Audit dengan Kepuasan Kerja Sebagai Variabel Pemoderasi. 19(1), pp.30-34. http://dx.doi.org/10.22225/we.19.1.1578.30-34

\begin{abstract}
This study aims to influence independence and professionalism on audit quality with job satisfaction as moderating variables. The research was conducted at the Public Accounting Office located in the Bali Region. The population of this research is all auditors who work at the Public Accountant Office in Bali with a purposive sampling technique to obtain a sample of 112 auditors. Data is collected using questionnaires. Data analyzed uses Moderated Regression Analysis. The results of the study show that 1) Independence has a positive effect on audit quality at the Public Accounting Firm in Bali. 2) Professionalism has a positive effect on audit quality at the Public Accountant Office in Bali. 3) Job Satisfaction strengthens the influence of Independence on audit quality at the Public Accounting Firm in Bali. 4) Job Satisfaction strengthens the influence of audit Professionalism on audit quality at the Public Accounting Firm in Bali.
\end{abstract}

Keywords: Independence; professionalism; audit quality; job satisfaction

\begin{abstract}
Abstrak-Penelitian ini bertujuan untuk Pengaruh lndependensi dan Profesionalisme Terhadap Kualitas audit dengan Kepuasan Kerja sebagai Variabel Pemoderasi. Penelitian dilakukan di Kantor Akuntan Publik yang berada di Wilayah Bali. Populasi penelitian ini adalah seluruh auditor yang bekerja pada Kantor Akuntan Publik di Bali dengan teknik purposive sampling sehingga diperoleh sampel sebanyak 112 Auditor. Data dikumpulkan dengan menggunakan kuisioner. Data dianalsis mengguanakan Moderated Regression Analysis. Hasil penelitian menunjukan bahwa 1) Independensi berpengaruh positif terhadap kualitas audit pada Kantor Akuntan Publik di Bali. 2) Profesionalisme berpengaruh positif terhadap kualitas audit pada Kantor Akuntan Publik di Bali. 3) Kepuasan Kerja memperkuat pengaruh Independensi terhadap kualitas audit pada Kantor Akuntan Publik di Bali. 4) Kepuasan Kerja memperkuat pengaruh Profesionalisme audit pada kualitas audit pada Kantor Akuntan Publik di Bali.
\end{abstract}

Kata Kunci: Independensi; profesionalisme; kualitas audit; kepuasan kerja

\section{PENDAHULUAN}

Zaman era globalisasi ini, setiap perusahaan saling berkompetisi agar terlihat lebih baik dibandingkan pesaing-pesaingnnya, salah satunya dalam hal pelaporan keuangan perusahaan. Laporan keuangan perusahaan dituntut menyajikan informasi yang akurat, dan dapat dipercaya agar tidak menimbulkan penyimpangan bagi pemakai laporan tersebut Pentingnya hal tersebut dilakukan agar terpenuhinya kebutuhan masing-masing pihak yang berkepentingan. Reliabilitas dan relevansi dari laporan keuangan dibutuhkan untuk meyakinkan pihak luar, karena hal tersebut merupakan alasan perusahaan mempercayakan kepada pihak ketiga yaitu akuntan publik independen untuk melakukan pemeriksaan laporan keuangan perusahaan. Dalam melaksanakan tugas seorang auditor hendaknya fokus dengan tugasnya.

Kualitas audit adalah komponen yang sangat krusial, karena kualitas audit yang baik dituntut agar menghasilkan laporan keuangan yang relevan dan kredibel sebagai dasar pengambilan keputusan. Hasil audit baik dalam bentuk laporan keuangan dengan tranparansi yang baik, dapat dipertanggungjawabkan dan sesuai dengan SAK yang berlaku, mampu meningkatkan kinerja perusahaan dan nantinya hasil laporan keuangan tersebut dapat dilihat oleh pemegang kebijakan yang memiliki kepentingan serta mencerminkan citra perusahaan dimata masyarakat (Angelo, 1981) menyatakan kualitas audit sebagai bentuk kemungkinan di mana auditor akan menemukan dan melaporkan pelanggaran yang ada pada sistem akuntansi.

Hingga kini masih terdapat keraguan terhadap akuntan publik oleh pengguna laporan keuangan karena tingginya kasus skandal yang melibatkan akuntan publik. Kasus Skandal Enron merupakan 
salah satu fenomena dimana Kantor Akuntan Publik Andersen terbukti bersalah akibat terindikasi terlibat dalam hal manipulasi data keuangan Enron dan berdampak pada kepailitan perusahaan tersebut Skandal di Indonesia terlihat dari akan diambilnya tindakan oleh Majelis Kehormatan Ikatan Akuntan Indonesia (IAI) terhadap 10 Kantor Akuntan Publik yang melakukan pelanggaran. Sepuluh Kantor Akuntan Publik tersebut terindikasi terlibat pelanggaran berat saat melakukan audit bankbank yang dilikuidasi pada tahun 1998, selain itu juga terdapat kasus keuangan dan manajerial perusahaan publik yang tidak bisa terdeteksi oleh akuntan public sehingga menyebabkan perusahaan didenda oleh Bapepam (Christiawan, 2000). Contoh dalam kasus yang telah dipaparkan menunjukan bahwa sikap indepensi auditor dan profesionalisme auditor sangat diperlukan auditor dalam melaksanakan kewajibannya.

Independensi adalah salah satu aspek krusial yang hendaknya dimiliki oleh Akuntan Publik dalam melaksanakan pemeriksaan laporan keuangan. Standar Auditing Seksi 200.18 (SA: 2013) menyebutkan bahwa independen bagi seorang akuntan publik artinya kemampuan auditor untuk merumuskan suatu opini audit tanpa dapat dipengaruhi. Dengan demikian auditor tidak dibenarkan mendukung kepada siapapun, sebab sebaik apapun keahlian teknis yang dimiliki, ia akan kehilangan sikap tidak memihak yang tentu sangat diperlukan untuk mempertahankan objektivitas pendapatnya. Dalam menjalankan tugasnya sebagai seorang Akuntan Publik tidak dibenarkan untuk terpengaruh oleh kepentingnn siapapun dalam melaksanakan tugasnya. Baik itu manejemen ataupun pemilik perusahaan. Hasil penelitian (Futri, 2014) menyatakan bahwa independensi auditor tidak berpengaruh terhadap kualitas audit.

Selain sikap independensi maka terdapat aspek lain yang hendaknya dimiliki sebagai seoran Akuntan Publik yaitu profesionalisme. Menurut (Ares \& Loebbecke, 2008) profesionalisme adalah suatu bentuk tanggung jawab yang dimiliki lebih dari sekadar memenuhi tanggung jawab yang dibebankan kepadanya dan lebih dari sekedar memenuhi peraturan masyarakat dan undang-undang. Penelitian (Futri, 2014) menemukan Profesionalisme auditor tidak memiliki pengaruh terhadap kualitas audit.

Kepuasan kerja hendaknya dituntut agar dimiliki oleh Akuntan Publik. Dikatakan demikian karena kepuasan kerja akuntan kadang memengaruhi hasil penilaian kualitas audit. Ketika seseorang puas terhadap pekerjaan yang ditekuni, maka rasa senang pun akan datang, terlepas dari rasa tertekan, sehingga akan rasa aman nyaman lingkungan kerjanya. Hasil penelitian (Futri, 2014) menemukan yaitu kepuasan kerja aditor berpengaruh positif terhadap kualitas audit.

Beberapa hasil penelitian sejenis yang telah dilakukan, menunjukan adanya ketidakkonsistenan maka perlu diteliti kembali mengenai pengaruh independensi dan profesionalisme auditor terhadap kualitas audit, dengan penambahan kepuasan kerja sebagai variabel pemoderasi. Keistimewaan peneltian ini yaitu adanya dugaan bahwa kepuasan kerja sebagai variabel moderasi, dengan dasar pertimbangan ketidakkonsistenan dari basil penelitian sebelumnya. Peneliti menduga bahwa variable kepuasan kerja dapat memperkuat atau memperlemah independensi dan profesionalisme terhadap kualitas audit. Berdasarkan hal tersebut, maka peneliti mengangkat judul "Pengaruh Independensi dan Profesionalisme Terhadap Kualitas Audit dengan Kepuasan Kerja sebagai Variabel Pemoderasi (Studi Empiris pada Kantor Akuntan Publik di Bali)".

Berdasarkan latar belakang masalah yang dipaparkan di atas, maka perumusan masalah dari penelitian ini adalah. Apakah independensi berpengaruh terhadap kualitas audit?, Apakah profesionalisme berpengaruh terhadap kualitas audit?,Apakah kepuasan kerja auditor memperkuat pengaruh independensi terhadap kualitas audit?, Apakah kepuasan kerja auditor memperkuat pengaruh profesionalisme terhadap kualitas audit?

Berdasarkan latar belakang dan pokok pennasalahan di atas, maka tujuan dari penelitian ini adalah. Untuk mengetahui pengaruh independensi terhadap kualitas audit. Untuk mengetahui pengaruh profesionalisme terhadap kualitas audit. Untuk mengetahui kepuasan kerja auditor memperkuat pengaruh independensi terhadap kualitas audit. Untuk mengetahui kepuasan kerja auditor memperkuat pengaruh profesionalisme terhadap kualitas audit

\section{KAJIAN TEORI}

\section{Kualitas Audit}


Menurut (Enofe, Okunega, Nbgame, \& Ediae, 2013), audit adalah pemeriksaan audit independen atas laporan keuangan suatu perusahaan yang telah dipersiapkan oleh manajemen perusahaan. (Angelo, 1981) mendefinisikan kualitas audit sebagai kemungkinan dimana auditor akan menemukan dan melaporkan pelanggaran yang ada dalam system akuntansi.

Penelitian ini menggunakan kuesioner pada penelitian Junanta (2015) untuk mengukur kualitas audit yang terdiri atas 8 item pernyataan. Indikator yang digunakan pada variabel ini antara lain kesesuaian pemeriksaan dengan standar audit dan kualitas laporan hasil audit.

\section{Independensi}

Independensi merupakan suatu standar auditing yang penting karena opini akuntan independen bertujuan untuk menambah kredibilitas laporan keuangan yang disajikan oleh manajemen. Seorang auditor yang memiliki independensi tinggi maka kinerjanya akan menjadi lebih baik.

Independensi berarti sikap mental yang bebas dari pengaruh, tidak dikendalikan oleh orang lain, tidak tergantung pada orang lain. Independensi juga diartikan adanya kejujuran diri auditor dalam mempertimbangkan fakta dan menyatakan pendapatnya. Penelitian ini menggunakan kuesioner untuk mengukur independensi yang terdiri atas 14 item pernyataan. Indikator yang digunakan pada variabel ini antara lain lama hubungan dengan klien, tekanan dari klien, telaah dari rekan auditor, danjasa non audit (Futri, 2014).

\section{Profesionalisme}

Menurut (Futri, 2014) profesiolisme lebih diartikan pada sikap clan perilaku seseorang dalam melaksanakan profesinya. Sikap profesionatisme merupakan salah satu syarat utama bagi siapapun yang meniadi auditor disamping memiliki keahlian yang memadai dan sikap disiplin serta konsisten dalam menjalankan pekerjaan sebagai seorang auditor.

Profesionalisme adalah salah satu syarat utama bagi siapapun yang ingin menjadi auditor selain memiliki keahlian atau skill yang memadai serta sikap disiplin dan konsisten dalam menjalankan pekerjaan sebagai seorang auditor. Penelitian ini mengukur profesionalisme dengan menggunakan kuesioner pada penelitian (Futri, 2014) yang terdiri atas 16 item pernyataan. Indikator yang digunakan pada variabel ini antara lain pengabdian profesi, kewajiban sosial, kemandirian, dan keyakinan terhadap peraturan profesi.

\section{Kepuasan Kerja}

Kepuasan kerja adalah suatu keadaan emosional individu, dimana keadaan menyenangkan atau tidak rnenyenangkan menurut sisi dan pandangan karyawan itu sendiri. Penelitian ini menggunakan kuesioner untuk mengukur kepuasan kerja (Futri, 2014) yang terdiri atas 5 item pernyataan. Indikator yang digunakan pada variabel ini antara lain gaji, kondisi pekerjaan, kelompok kerja, dan promosi.

\section{METODE}

Pendekatan yang digunakan pada penelitian ini adalah pendekatan kuantitatif yang berbentuk asosiatif. Penelitian kuantitatif menekankan pengujian teori melalui pengukuran variabel penelitian dengan angka serta data dianalisis dengan menggunakan prosedur statistik. (Sugiyono, 2014) menyebutkan penelitian Asosiatif adalah dugaan tentang adanya hubungan antar variabel dalam populasi yang akan diuji melalui hubungan antar variabel dalam sampel yang diambil dari populasi tersebut. Penelitian ini akan menguji variabel independensi dan profesionalisme pada kualitas audit dengan kepuasan kerja sebagai pemoderasi.

Data dalam penelitian ini adalah data primer yang diperoleh dari jawaban responden melalui kuesioner dan data jumlah auditor yang terdapat di 13 Kantor Akuntan Publik di Bali. Data kuantitatif adalah data yang berbentuk angka (Sugiyono, 2014). Data kuantitatif dalam penelitian ini adalah jumlah kuesioner dan yang berupa jawaban responden yang diukur dengan bantuan Skala Likert.

Metode pengumpulan data yang digunakan dalam penelitian ini adalah metode survei dengan teknik kuesioner. Kuesioner merupakan metode pengumpulan data yang dilakukan dengan cara memberi pertanyaan atau pernyataan tertulis kepada responden.

Penelitian ini menggunakan analisis regresi linier berganda dan MRA. MRA merupakan uji khusus regresi linear berganda, dimana dalam persamaan regresinya mengandung unsur interaksi 
(perkalian dua atau lebih variabel independen). Uji analisis koefisien regresi akan menggunakan uji Moderated Regression Analysis (MRA). Memilih MRA dalam penelitian ini menjelaskan variabel pemoderasi dalam memperkuat atau memperlemah hubungan antara variabel independen dan dependen. Perhitungan statistik akan dianggap signifikan apabila nilai ujinya berada dalam daerah kritis (daerah dimana Ho ditolak). Sebaliknya, apabila nilai uji berada di luar daerah kritis (Ho diterima), maka perhitungan statistiknya tidak signifikan. Model regresi dalam penelitian ini ditunjukan dengan persamaan sebagai berikut.

$$
\begin{aligned}
& \mathrm{y}=\alpha+\beta 1 \mathrm{X} 1+\beta 2 \mathrm{X} 2+\beta 3 \mathrm{Z}+\beta 4 \mathrm{X} 1 \mathrm{Z}+\beta 5 \mathrm{X} 2 \mathrm{Z}+\varepsilon \\
& \text { Keterangan: } \\
& \mathrm{Y} \quad=\text { Kualitas Audit } \\
& \alpha \quad=\text { Konstanta } \\
& \beta 1-\beta 5 \quad=\text { Koefisien } \\
& \mathrm{X} 1 \quad=\text { Independensi Auditor } \\
& \mathrm{X} 2 \quad=\text { Profesionalisme Auditor } \\
& \mathrm{Z} \quad=\text { Kepuasan Kerja Auditor } \\
& \varepsilon \quad=\text { Eror }
\end{aligned}
$$

\section{HASIL PENELITIAN DAN PEMBAHASAN}

\section{Pengaruh Independensi Terhadap Kualitas Audit}

Berdasarkan hasil analisis yang dilakukan, dapat dilihat nilai signifikan untuk variabel Independensi sebesar 0,003 kurang dari $0,05(0,000<0,05)$ dengan nilai koefisien positif 0,445 , sehingga H0 ditolak, dengan kata lain Independensi berpengaruh positif terhadap kualitas audit. Hal ini berarti semakin meningkat Independensi auditor maka kulitas audit akan semakin meningkat kualitas audit, sebaliknya semakin menurun Independensi auditor maka kualitas audit akan semakin menurun.

\section{Pengaruh Profesionalisme Terhadap Kualitas Audit}

Berdasarkan hasil analisis yang dilakukan, dapat dilihat nilai signifikan untuk variabel Profesionalisme sebesar 0,000 kurang dari $0,05(0,000<0,05)$ dengan nilai koefisien positif 1,386, sehingga H0 ditolak, dengan kata lain Profesionalisme berpengaruh positif pada kualitas audit. Hal ini berarti semakin meningkat Profesionalisme maka kualitas audit akan semakin meningkat pula, sebaliknya semakin menurun Profesionalisme maka kualitas audit akan semakin menurun.

\section{Pengaruh Independensi Terhadap Kualitas Audit dengan Kepuasan Kerja Sebagai Variabel Moderasi}

Berdasarkan hasil analisis yang dilakukan, dapat dilihat nilai signifikan untuk variabel Independensi dengan Kepuasan Kerja sebagai pemoderasi sebesar 0,001 kurang dari 0,05 $(0,001<0,05)$ dengan nilai koefisien positif 0,028 , sehingga $\mathrm{H} 0$ ditolak, dengan kata lain Kepuasan Kerja memperkuat pengaruh Independensi terhadap kualitas audit. Hal ini berarti semakin meningkat Independensi dengan Kepuasan Kerja seorang auditor sebagai pemoderasi maka kulitas audit akan semakin meningkat atau, sebaliknya semakin menurun Independensi dengan Kepuasan Kerja seorang auditor sebagai pemoderasi maka kualitas audit akan semakin menurun.

\section{Pengaruh Profesionalisme Terhadap Kualitas Audit dengan Kepuasan Kerja Sebagai Variabel Moderasi}

Berdasarkan hasil analisis yang dilakukan, dapat dilihat nilai signifikan untuk variabel Profesionalisme dengan Kepuasan Kerja sebagai pemoderasi sebesar 0,002 kurang dari 0,05 $(0,000<0,05)$ dengan nilai koefisien positif 0,059 , sehingga $\mathrm{H} 0$ ditolak, dengan kata lain Kepuasan Kerja memperkuat pengaruh Profesionalisme audit pada kualitas audit. Hal ini berarti semakin meningkat Profesionalisme dengan Kepuasan Kerja seorang auditor sebagai pemoderasi maka kulitas audit akan semakin meningkat pula atau, sebaliknya semakin menurun Profesionalisme dengan Kepuasan Kerja seorang auditor sebagai pemoderasi maka kualitas audit akan semakin menurun pula.

Dengan adanya sikap Profesionalisme dari seorang auditor dan diperkuat dengan kepuasan auditor dengan pekerjaannya, maka auditor tersebut diharapkan dapat bekerja dengan lebih baik sehingga berdampak pada semakin meningkatnya kualitas. Dengan demikian dapat dinyatakan bahwa Kepuasan Kerja memperkuat pengaruh Profesionalisme audit pada kualitas audit. 


\section{SIMPULAN}

Berdasarkan hasil analisis penelitian dan hasil pembahasan pada bab sebelumnya maka simpulan dari penelitian ini adalah sebagai berikut:

Independensi berpengaruh positif terhadap kualitas audit pada Kantor Akuntan Publik di Bali. Hal ini berarti semakin meningkat Independensi auditor pada Kantor Akuntan Publik di Bali maka kualitas audit pada Kantor Akuntan Publik di Bali akan semakin meningkat, sebaliknya semakin menurun Independensi auditor pada Kantor Akuntan Publik di Bali maka kualitas audit pada Kantor Akuntan Publik di Bali akan semakin menurun.

Profesionalisme berpengaruh positif terhadap kualitas audit pada Kantor Akuntan Publik di Bali. Hal ini berarti semakin meningkat Profesionalisme pada Kantor Akuntan Publik di Bali maka kualitas audit pada Kantor Akuntan Publik di Bali akan semakin meningkat, sebaliknya semakin menurun Profesionalisme pada Kantor Akuntan Publik di Bali maka kualitas audit pada Kantor Akuntan Publik di Bali akan semakin menurun.

Kepuasan Kerja memperkuat pengaruh Independensi terhadap kualitas audit pada Kantor Akuntan Publik di Bali. Hal ini berarti semakin meningkat Independensi auditor pada Kantor Akuntan Publik di Bali dengan Kepuasan Kerja seorang auditor sebagai pemoderasi maka kualitas audit pada Kantor Akuntan Publik di Bali akan semakin meningkat atau, sebaliknya semakin menurun Independensi auditor pada Kantor Akuntan Publik di Bali dengan Kepuasan Kerja seorang auditor sebagai pemoderasi maka kualitas audit pada Kantor Akuntan Publik di Bali akan semakin menurun. Maka dapat disimpulkan bahwa Kepuasan Kerja seorang auditor dapat memperkuat pengaruh Independensi terhadap kualitas audit pada Kantor Akuntan Publik di Bali.

Kepuasan Kerja memperkuat pengaruh Profesionalisme audit pada kualitas audit pada Kantor Akuntan Publik di Bali. Hal ini berarti semakin meningkat Profesionalisme dengan Kepuasan Kerja seorang auditor sebagai pemoderasi maka kualitas audit pada Kantor Akuntan Publik di Bali akan semakin meningkat pula atau, sebaliknya semakin menurun Profesionalisme dengan Kepuasan Kerja seorang auditor sebagai pemoderasi maka kualitas audit pada Kantor Akuntan Publik di Bali akan semakin menurun pula. Maka dapat disimpulkan bahwa Kepuasan Kerja seorang auditor dapat memperkuat pengaruh Profesionalisme terhadap kualitas audit pada Kantor Akuntan Publik di Bali.

\section{DAFTAR PUSTAKA}

Angelo, L. . De. (1981). Auditor Independence, Low Balling and Disclosure Regulation. Journal Accounting and Economics, 3(2), 113-127. Retrieved from https://econpapers.repec.org/article/eeejaecon/ v_3a3_3ay_3a1981_3ai_3a2_3ap_3a113-127.html

Ares, A. ., \& Loebbecke. (2008). A uditing Pendekatan Terpadu. Jakarta: Salemba Empat.

Christiawan, Y. J. (2000). Konsep Pengauditan Dalam Lingkungan Pengelohan Data Akuntansi Terkomputerisasi. Jurnal Akuntansi Dan Keuangan Universitas Kristen Petra, 2(1), 9-20. Retrieved from https://www.neliti.com/publications/73566/konsep-pengauditan-dalam-lingkungan-pengelohan-dataakuntansi-terkomputerisasi

Enofe, D., Okunega, A. ., Nbgame, D. C., \& Ediae, E. C. O. O. (2013). Audit Quality and Auditors Independence in Nigeria: An Empirical Evaluation Reseacrh. Journal of Finance And Accounting. Retrieved from http://www.sciencepublishinggroup.com/journal/archive?journalid=171\&issueid=1710101

Futri, P. S. (2014). Pengaruh Independensi, Profesionalisme, Tingkat Pendidikan, Etika Profesi, Pengalam dan Kepuasan Kerja Auditor Terhadap Kualitas Audit pada Kantor Akuntan Publik di Bali. E-Jurnal Akuntansi, 7(2). Retrieved from https://ojs.unud.ac.id/index.php/Akuntansi/article/view/8918

Sugiyono. (2014). Metode Penelitian Bisnis. Bandung: Alfabeta. 